\title{
THE CONCEPT OF AMÂNAH IN INFORMED CONSENT
}

\author{
Zulham \\ Shari'ah Faculty of State Institute for Islamic Studies, North Sumatra \\ Jl. Williem Iskandar Pasar V, Medan Estate, North Sumatra \\ E-mail: heam_akhtar@yahoo.co.id
}

\begin{abstract}
Abstrak: Konsep Amânah dalam Persetujuan Tindakan Medik. Putusan Kasasi Mahkamah Agung Republik Indonesia Nomor 365K/Pid/2012 mengabulkan gugatan kasasi Jaksa Penuntut Umum Kejaksaan Negeri Manado. Mahkamah Agung menganulir putusan Pengadilan Negeri Manado yang menjatuhkan sanksi pidana penjara 10 (sepuluh) bulan kepada masing-masing terdakwa. Ikatan Dokter Indonesia (IDI) berpendapat bahwa perjanjian antara dokter dan pasien adalah perjanjian dalam proses, bukan perjanjian berdasarkan hasil. Putusan kasasi ini memberikan kesempatan kepada para ahli hukum untuk menguji dan mengevaluasi konsep persetujuan tindakan medik secara filosofis dan yuridis. Tulisan ini mengemukakan bahwa konsep persetujuan tindakan medik harus dibangun berdasarkan kerangka amânah yang merupakan suatu konsep penting dalam hukum Islam.
\end{abstract}

Kata kunci: amânah, persetujuan tindakan medik, hukum kesehatan, hukum perlindungan konsumen

\begin{abstract}
The Concept of Amânah in Informed Consent. The Appeal Decision of the Supreme Court of the Republic of Indonesia Number 365K/Pid/2012 granted the appeal request of Public Prosecutor of Manado State Public Prosecutor's Office. The Supreme Court annulled the Manado State Court Decision that imposed 10 (ten) months criminal imprisonment to each defendant. The Indonesian Doctors Association argued that the contract between doctor and patient is a contract of process, not a contract of result. At the very least, this Appeal Decision provided an opportunity for legal experts to test and evaluate the concept of informed consent both philosophically and juridically. This paper argues that informed consent should be built on the framework of amânah which is an important concept in Islamic law.
\end{abstract}

Keywords: amânah, informed consent, health law, consumer protection law

\section{Introduction}

The Appeal Decision of the Supreme Court of the Republic of Indonesia (Putusan Kasasi Mahkamah Agung Republik Indonesia) Number 365K/Pid/2012 ${ }^{1}$ annulled the Manado State Court Decision (Putusan Pengadilan Negeri Manado) Number 90/PID.B/2011/ PN.MDO. ${ }^{2}$ The Manado State Court Decision stated that the first defendant (terdakwa I) dr. Dewa Ayu Sasiary Prawani, the second defendant (terdakwa II) dr. Hendry Simanjuntak and the third defendant (terdakwa III) dr. Hendy Siagian has not been proven legitimately and conclusively guilty in the criminal charges contained in the indictment, as well as acquitting the first defendant, the second defendant and the third defendant of all criminal charges (vrijspraak). ${ }^{3}$

Received: 25th October 2013, reveised: 25th November 2013, accepted: 15th December 2013.

${ }^{1}$ See Putusan Kasasi Mahkamah Agung Republik Indonesia N mor 365K/Pid/2012.

${ }^{2}$ See Putusan Pengadilan Negeri Manado Nomor 90/PID.B/2011/ PN.MDO.

${ }^{3}$ See Putusan Pengadilan Negeri Manado Nomor 90/PID.B/2011/
Based on the appeal submitted by the Public Prosecutor (Jaksa Penuntut Umum/JPU) of the Manado State Public Prosecutor's Office (Kejaksaan Negeri Manado), the Supreme Court through the Appeal Decision Number 365K/Pid/2012 judged and granted the appeal and annulled the Manado State Court Decision Number 90/PID.B/2011/PN.MDO. Further the Supreme Court judged by itself and decided that the first defendant, second defendant, and third defendant has been proven legitimately and conclusively guilty of the criminal charge due to action caused by negligence which resulted in the death of others as well as convicting the defendants with imprisonment for 10 (ten) months each. ${ }^{4}$ The Appeal Decision of the Supreme Court examined several legal facts, one of which could still be debated philosophically and juridically which is informed consent.

Indonesian Doctor Association (Ikatan Dokter

\footnotetext{
PN.MDO.

${ }^{4}$ See Putusan Kasasi Mahkamah Agung Republik Indonesia Nomor 365K/Pid/2012.
} 
Indonesia/IDI) argued that the Supreme Court verdict is a criminalization of doctor's profession. ${ }^{5}$ As such, IDI has urged doctors to demonstrate against the verdict. ${ }^{6}$ IDI further argued that the contract between doctor and patient is a contract of process not a contract of result. ${ }^{7}$ IDI regretted the use of KUHP (Kitab Undangundang Hukum Pidana, Criminal Law Sourcebook/ Indonesian Penal Code) to judge cases arising out of medical treatments. ${ }^{8}$ This development has provided an impetus to review the Law of Doctor's Practice (UndangUndang Praktik Kedokteran) as doctors need the sense of security when performing their profession to prevent criminalization against them. ${ }^{9}$ Doctor's nationwide demonstration has caused a drastic reduction of public health service and a consequent tension in the relationship between doctors and patients. ${ }^{10}$ This saga has provided the impetus for much needed evaluation of Indonesian health law, such that it could provide more elegantly and unbiased legal certainty between doctors and patients.

The concept of state's role in public health begins with the theory of protection where the state is obligated to protect the public by provided health services. ${ }^{11}$ This concept then develops into the theory of right where the public as citizens have the rights to obtain health services. ${ }^{12}$ These reasons caused the amendment of the 1945 Republic of Indonesia Constitution (UndangUndang Dasar Republik Indonesia Tahun 1945, UUD 1945), in which principally the guarantee of health insurance is regulated under Article $28 \mathrm{H}$ Clause (1) ${ }^{13}$

${ }^{5}$ Sindonews.com, "Demo Dokter", in http://daerah.sindonews. com, accessed on 2nd October 2013.

${ }^{6}$ Tribunnews.com, "Dokter Mogok Nasional", in http://www. tribunnews.com/kesehatan, accessed on 2nd October 2013.

Zainal Abidin, "Bisakah Dokter Dipenjarakan?", in Indonesia Lawyer Club Talk Show TVOne, Tuesday, 8th October 2013.

8 Anonim, "IDI Sesalkan Penggunaan KUHP pada Kasus Tindakan Medis Dokter", in http://health.okezone.com, accessed on 2nd October 2013.

9 Republika Online, "Politikus Minta Kriminalisasi Dokter Disikapi secara Arif", in http://www.republika.co.id/berita/nasional/ hukum, accessed on 2nd October 2013.

${ }^{10}$ Tempo.com, "Menyoal Demonstrasi Dokter", Friday, in http:// www.tempo.co/read/kolom, accessed on 3th October 2013.

${ }^{11}$ The function of government to protect all individuals, as long as it is faithful to this pledge, the government cannot be denied its power but when it ceases to do it, its laws have no validity and the government may be overthrown. Hari Chand, Modern Jurisprudence, (Kuala Lumpur: International Law Book Services: 1994), p. 45.

${ }^{12}$ Without the health law the legal branch of health law will not be complete when we take the right of health and life as the goal. Wu Chongqi, Law, Health Law and Science of Health Law, in World Association for Medical Law, August-December 2012, Vol. 4, p. 5.

${ }^{13}$ Article 28H clause (1) UUD 1945 states that "Each person has a right to a life of well-being in body and mind, to a place to dwell, to enjoy a good and healthy environment and to receive medical care". and Article 34 Clause (3) $)^{14}$ of UUD 1945. Based on this foundational constitution ${ }^{15}$, public health service provision is arranged further under lower-level regulations. ${ }^{16}$

The Constitution of the World Health Organisation $(\mathrm{WHO}){ }^{17}$ stated that "The enjoyment of the highest attainable standard of health is one of the fundamental rights of every human being...”. ${ }^{18}$ The issue of health law has been developing for a long time, along with the development of consumer protection law. ${ }^{19}$ However, officially the development of health law in the world at large started since the First Congress of World Association for Medical Law in 1967 to guarantee public health rights. Berna Arda elaborated that human rights concept has three stages: (1) One contains mostly personal rights, such as equality, freedom, personal

\footnotetext{
${ }^{14}$ Article 34 clause (3) states that "The state has the responsibility to provide proper medical and public service facilities".

15 The terms constitution and foundational law (Undang-Undang Dasar) are often debated among legal experts, whether it is derived from constitution (English), grondwet (Dutch) and gerundgesetz (German). In general constitution is defined broader than foundational law as constitution covers written and unwritten aspects. Moh. Mahfud Md, Perdebatan Hukum Tata Negara Pasca Amandemen Konstitusi, (Jakarta: LP3ES, 2007), p. xi-xii. Jimly elaborated that constitution in general rests on three consensual elements, which are: (1) The consensus of common purpose or aspiration (the general goals of society or general acceptance of the same philosophy of government). (2) The consensus of rule of law as the foundation of government and management of state (the basis of government). (3) The consensus of institutional forms and state procedures (the form of institutions and procedures). Jimly Asshiddiqie, Konstitusi dan Konstitusionalisme Indonesia, (Jakarta: Sekretariat Jenderal dan Kepaniteraan Mahkamah Konstitusi Republik Indonesia, 2006), p. 25. While A.V. Dicey proposed three main elements of a state of law, which are: supremacy of law, equality before the law and constitution based on individual rights. A.V. Dicey, Introduction to the Study of the Law of the Constitution, (Indianapolis: Liberty Fund, 1982), p. 123-187.

${ }^{16}$ Among them are Law Number 29 Year 2004 on Medical Practice (Undang-Undang Nomor 29 Tahun 2004 tentang Praktik Kedokteran), Law Number 40 Year 2004 on National Social Security System (Undang-Undang Nomor 40 Tahun 2004 tentang Sistem Jaminan Sosial Nasional), Law Number 36 Year 2009 on Health (Undang-Undang Nomor 36 Tahun 2009 tentang Kesehatan). Juridically Law of Medical Practice (Undang-Undang Praktik Kedokteran) and Law of Health (UndangUndang Kesehatan) implements the provision of Article 34 clause (3) UUD 1945, while Law on National Social Security System implements the provision of Article 34 clause (2) UUD 1945 which states "The state develops a social security system for everybody and empowers the weak and underprivileged in society in accordance with their dignity as human beings". Social security mentioned could also be understood as health provision guarantee to society.

${ }^{17}$ WHO's Constitution came into force on 7 April 1948, a date we now celebrate every year as World Health Day. http://www.who.int/ about/history/en/index.html, accessed on 6th Juli 2013.

${ }^{18}$ Anonim, "Health and Human Rights", in http://www.who.int/ hhr/en, accessed on 6th October 2013.

${ }^{19}$ Tragedy Elixir Sulfanilamide, a type of medicine from sulphur, in 1937 causes 93 consumers in the United States to die. Laurence P. Feldman, Consumer Protection, Problems and Prospect, (St. Paul: West Publishing, 1977), p. 14.
} 
security, political rights and owner's right. (2) Stage human rights can be characterized as economical, social and cultural rights. (3) Stage of human rights arised at the second half of the 20th century. And human rights such as peace, living in a healthy environment, patient's rights and consumer rights are part of third stage rights. Because of the collective feature of these third stage human rights these also named as solidarity rights. ${ }^{20}$

Agreeing with the above idea, Yutaka AraiTakahashi elaborated the right to health is conceptually or practically interwoven with other economic, social and cultural rights, such as the right to work, food, clothing, housing, education and social security. That the protective scope of the right to education can be extended to an individual entitlement to education on nutrition prenatal or post natal care suggests that other stand-alone economic and social rights have considerable bearing on health. ${ }^{21}$

The idea of health law provides guarantee to the public that they would obtain the necessary health service. In health law informed consent is an important factor of doctor and patient relationship. The verdict of the Supreme Court is closely related to this idea. ${ }^{22}$ What is the real foundation of informed consent philosophy? How is informed consent implemented? How is informed consent related to the concept of amânah? The answers to this question would be viewed from the perspective of health law and consumer protection law which would be discussed in this paper.

This paper aims to elucidate the concept of amânah in relation to informed consent with regards to doctor and patient relationship viewed from the perspective of health law and consumer protection law. Islamic law as one of the sources of law in Indonesia could be utilized to examine doctor and patient relationship especially

${ }^{20}$ Berna Arda, Informed Consent Right and Children, (Beijing: Book of Abstracts, 17th World Congress on Medical Law, 2008), p. 95 and Roberia, Paradigma Jaminan Kesehatan Semesta, Proposal Disertasi Universitas Indonesia, 2012, p. 30

${ }^{21}$ Yutaka Arai-Takahashi, "The Right to Health in International Law; A Critical Apprasial", in Robyn Martin and Linda Johnson (ed), Law and the Public Dimension of Health, (London: Cavendish Publishing Limited, 2001), p. 161.

${ }^{22}$ See Putusan Kasasi Mahkamah Agung Republik Indonesia Number 365K/Pid/2012. Indeed the Constitutional Court through Putusan Nomor 4/PUU-V/2007 decided that the threat of criminal imprisonment and incarceration regulated in Article 75 clause (1), Article 76, and Article 79 letter c (about words "or letter e") Law Number 29 Year 2004 on Medical Practice, contradicts UUD 1945 and does not possess legal binding force as they induce threat and fear in doctors performing medical practice and providing medical service to the public. But the verdict of the Constitutional Court (Mabkamah Konstitusi) does not immediately eliminate all criminal threat in medical practice. See Article 51 Law Number 29 Year 2004 on Medical Practice. issues related to informed consent where the concept of amânah in Islamic law is the philosophical foundation for all human activities, as all contracts (al-'aqd) is begun with the concept of amânah.

Using juridical normative methodology with statutes approach presented under qualitative methodology, this study analyzed legal foundations and legal norms of informed consent from the perspective of health law and consumer protection law. Foundations, norms and doctrines contained in the Alquran, Hadith, Islamic law and other laws such as legal norm contained in state regulations were analyzed. Statutes approach is conducted through the analysis of state regulations related to informed consent which is the 1945 Foundational Law of the Republic of Indonesia, the Law Number 29 Year 2004 on Medical Practice (Praktek Kedokteran), the Law Number 36 Year 2009 on Health (Kesehatan) and the Law Number 8 Year 1999 on Consumer Protection (Perlindungan Konsumen). Data were analyzed qualitatively, exhaustively, holistically and comprehensively to elucidate the concept of amânah in informed consent related to doctor and patient relationship.

\section{The Concept of Amânah in Islamic Law}

The word amanah in the Alquran is mentioned 6 (six) times, be it in the singular (mufrad) or plural (jama) form, as found in the verses: al-Baqarah [2]: 283, al-Nisâ’ [4]: 58, al-Anfâl [8]: 27, al-Mu’minûn [23]: 8, al-Ahzzâb [33]: 72 and al-Ma'ârij [70]: 32.

In addition of these verses, many other Alquran verses presented the messages and values of amânah. The word amanah originates from the Arabic word amina-yamanu and also amana-yuminu which means trustworthy (shiddîq) and îmân means believing, submitting and obeying what God has decreed. While amânah means trustworthy, its antonym being khiyânah (traitorous). ${ }^{23}$ Amânah does indeed possess a similarity of meaning with "trust" but between "amânah" and "trust" there is a philosophical difference. To implement amânah is a reflection of human servitude as God's creature as mentioned in the above verses. While to implement trust is a reflection of the concept benefit which ultimately has it source in materialism and utilitarianism as could be seen in the definition of trust in Blacks Law Dictionary, "The right, enforceable solely in equity, to the beneficial enjoyment of property to which another person holds the legal title; a property interest held by one person (the trustee) at the request of another (the settlor) for the

${ }^{23}$ Loys Ma'lûf, Al-Munjid fî al-Lughah, (Beirut-Lebanon: Dâr ElMachreq Sarl Publisher, 1986), p. 18. 
benefit of third party (the beneficiary)." 24

Ibn 'Arabî defined amânah as the entirety of action protected from fraud and its derivatives as well as action that must be fulfilled to the giver of amannah. ${ }^{25}$ Dawam Rahardjo opined that everything that is related to duty, obligation, right and responsibility could be referred to the concept of amânah as foundational value, ${ }^{26}$ hence amânah is an intention which must be paid attention to in all human activities.

Amânah is the entirety of responsibility accepted by someone given trust to perform an action as it should be $^{27}$ as such the concept of amanah possess 3 (three) elements, such as: Amânah giver, Amânah receiver and Amânah performed. The concept of amânah possesses a wide scope which could be classified into four aspects, which are: (1) The concept of amânah to God. ${ }^{28}$ (2) The concept of amânah to self. ${ }^{29}$ (3) The concept of amânah to others. ${ }^{30}$ and (4) The concept of amânah to the environment. ${ }^{31}$

Amânah actually begins from the creation of humans on earth (khaliffah fi al-ardh). ${ }^{32}$ Humans are given amânah to maintain the universe responsibly to create prosperity (mashla $\underline{h} a t)^{33}$ for all of mankind.

${ }^{24}$ Blacks Law Dictionary does indeed provide the definition of trust in the form of words, however all of them have roots in the concept of materialism. Bryan A. Garner, Black's Law Dictionary, (St. Paul, Minn: West Publishing, 2004), Eight Edition, p. 1546.

${ }^{25}$ Ibn 'Arabî, A $\underline{h} k \hat{a} m$ Al-Qurân, (Beirut: Dâr al-Kutub al-'Ilmiyyah, 2003), Juz I, p. 570-571. The argument of Ibn 'Arabî to not renege when given amânah is reinforced in Ibn 'Arabî, A $\underline{b} k \hat{a} m$ Al-Qurân, Juz III, p. 316.

${ }^{26}$ Dawam Rahardjo, Ensiklopedia Alquran; Tafsir Sosial Berdasarkan Konsep-Konsep Kunci, (Jakarta: Paramadina, 1996), p. 204.

${ }_{27}$ Amânah is something entrusted (deposited) to others. Pusat Bahasa Departemen Pendidikan Nasional, Kamus Besar Bahasa Indonesia, (Jakarta: Balai Pustaka, 2005), p. 35.

${ }^{28}$ All the amanah which is obligated on human comes in the form of God's rights towards its slaves, such as prayer, alms, fast, expiation (kafârat) and vow (nadzar), all of which are amânah entrusted without monitoring. 'Abd Allâh ibn Muhammad ibn 'Abd al-Raḩmân ibn Ishââ al-Syaykhî, Tafsîr Ibn Katsîr Jilid II, translated by M. Abdul Ghoffar E.M. (Jakarta: Pustaka Imam Syafi'i, 2005), p. 336.

${ }^{29}$ All amânah related to rights upon self, such as eating, drinking, sleeping and others is one of the concept of 'the purpose of law' (maqâshid al-syarîah) which is to preserve life. Abû Ishâq Ibrâhîm AlSyâthibî, al-Muwâfaqât fî̀ Ushûl al-Syarî̉ah, (Beirut: Dâr al-Kutub al'Ilmiyyah, 2004), Juz II, p. 16-25.

${ }^{30}$ All amânah related to other human rights, such as deposit, loan, promise and others which must be fulfilled. 'Abd Allâh ibn Muhammad ibn 'Abd al-Raḩmân ibn Ishâq al-Syaykhî, Tafsî̀ Ibn Katsîr, p. 336.

31 To safeguard the environment and the universe is amanah entrusted by God to humans where humans are obligated to fulfill the amânah. See Q.s. al-Baqarah [2]: 11, Q.s. al-A'râf [7]: 74, Q.s. al-Kahf [18]: 94, Q.s. al-Qashash [28]: 83 and Q.s. al-Rûm [30]: 41.

${ }^{32}$ Q.s. al-Baqarah [2]: 30.

${ }^{33}$ Etymologically, al-mashlahah could mean goodness, usefulness, appropriateness, worthiness, harmony, utility, benefit and interest. Mohammad Hashim Kamali, Principles of Islamic Jurisprudence, (Kuala
The concept of amânah in Islam consider the ability, qualification and integrity of the amânah receiver. The Prophet Muhammad when giving amânah to his companions always considers their ability to fulfill the amânah. There is a tradition that Abû Dzar once came to see the Prophet for a public position but was denied by the Prophet as he was considered weak..$^{34}$ This proves that the Prophet consider the ability of amânah receiver. Another story, this time in the Alquran, would be when the Prophet Yûsuf requested the position of state treasurer to the king. In fact, the Prophet Yûsuf has considered that he is able to fulfill the amânah that he requested. ${ }^{35}$

Such was the case for the speech of Abû Bakr when he was appointed caliph: "O People. I was entrusted as your ruler although I am not better than any one of you. Support me as long as you see me following the right path and correct me when you see me going astray. Obey me as long as I observe God in your affairs. If I disobey Him, you owe me no obedience. The weak among you are powerful (in my eyes) until I get them their due. The powerful you are weak (in my eyes) until I take away from them what is due to others. I say that and seek God's forgiveness for myself and for you" ${ }^{36}$

Abû Bakr's speech contains a very deep concept of amânah that he only wanted to be obeyed as long as he was considered to be in the right path and corrected and left behind when he strayed from the right path. This indicates that the amânah receiver could deviate at any given moment from the right path. Therefore a correction mechanism to maintain the fulfillment of amânah is needed.

\section{The Legal Relationship between Doctor and Patient}

Daldiyono pointed that doctor and patient relationship possess several evolving natures. First, religious nature where disease is considered to originate from the anger of Gods in which patient comes to Religious Leader for cure through religious means.

\footnotetext{
Lumpur: Ilmiah Publisher Sdn., 1998), p. 267. Kaidah aynamâ wujûd al-mashla hah fatsamma syar' Allâh (Where there is maslahat, there would be the law of God). Muhammad Sa'îd Ramadhân al-Bûthî, Zhawâbith al-Mashlabah fì al-Syarîah al-Islâmiyyah, (Beirut: Mu’assasah al-Risâlah, 1977), p. 12 and Zakariyâ al-Barrî, Mashâdir al-Ahkhâm al-Islâmiyyah, (Mesir: Dâr al-Ittihâd al-'Arabî, 1975), p. 129.

${ }^{34} \mathrm{Nasiruddin} \mathrm{Al-Barabbasi,} \mathrm{Kisah-Kisah} \mathrm{Islam} \mathrm{Anti} \mathrm{Korupsi,} \mathrm{(Ban} \mathrm{-}$ ung: Mizania, 2009), p. 54.

${ }^{35}$ Q.s. Yûsuf [12]: 55.

${ }^{36}$ Charles Kurzman, Modernist Islam 1840-1940, (New York: Oxford University Press, 2002), p. 93-94 and Suzanne McIntire, Speeches in World History, (New York: An Imprint of Infobase Publishing, 2009), p. 81-81.
} 
In this case the Religious Leader is viewed also as a doctor.

Second, paternalistic nature in subsequent generation specialization and division of labor occur. People with expertise to treat patient (who could be considered the first generation doctors), no longer use religious means. As the lay public does not understand the healing process an asymmetric relationship arises between doctor and patient. The dependency of patient to doctor is reinforced as doctor's orders must be obeyed by patient as only the doctor understand the science of healing. This model of relationship occurs since the 5 th century before the common era to the modern century before the development of information technology.

Third, service and consumption nature. The development of technology and information changes the relationship theory between doctor and patient from paternalistic to service provider and consumer relationship where the public becomes aware of its rights and able to evaluate doctor's work. However, this era of provider and consumer relationship resulted in a psychological distance between doctor and patient laden with business aspects. As such patient easily sue and doctor responds by providing medical service defensively.

Fourth, partnership and joint effort nature. This relationship format is very ideal where the doctor and patient must value and trust each other. This kind of partnership could be developed like familial relationship when the patient is aware and independent while the doctor is wise and acts virtuously. ${ }^{37}$

Such is also the explanation of Mason and Smith, very early medicine was, a matter of mystery there being no apparent natural reason why disease struck one person rather than another. The answer had to be round in the supernatural and supernatural powers being sparingly distributed, healing became a prerogative of a few whose power depended largely on the ignorance of others. At its inception, the medical profession was elitist and it is easy to imagine the transference of healing powers from the isolated tribal witch doctor to the priest of organised religion. ${ }^{38}$

Further, medical profession is a "common calling" to

${ }^{37}$ Daldiono, Pasien Pintar dan Dokter Bijak; Buku Wajib bagi Pasien dan Dokter, (Jakarta: Buana Ilmu Populer, 2007), p. 192-194. As a senior doctor, Daldiono explained that the relationship between doctor and patient should be proportional and balanced. He has also predicted that once there would be legal incidents in medical practice which would reach the court of law.

${ }^{38}$ J.K. Mason and R.A. McCall Smith, Law and Medical Ethic, (London: Butterworths, 1991), p. 3. protect the public. After the development of contract law, the principle of doctor's responsibility to protect the public is replaced with contractual relationship, starting from the request of patient for medical care and the fulfillment of the request by doctor to provide medical care. In the last decade the legal relationship between doctor and patient is dominated by tort of negligence which develops concurrently with the development of hospital industry not a few doctors have been judged based on this negligence principle. ${ }^{39}$

Duty of care which is imposed upon law on the doctor arises when the doctor agrees to treat the patients be the medical care requested explicitly or implicitly. As long as this relationship exists the doctor is obligated to treat the patient as long as necessary in medical practice. When this relationship is terminated, the doctor must agree to avoid the charge of abandoning the patient. The point of legal relationship between doctor and patient is both have freedom of choice except in emergency cases. In emergency cases, doctor has legal obligation to provide emergency care to anyone eventhough they are not his patients. In health law this is called the principle of duty to provide emergency services. ${ }^{40}$ As such Michael Davies pointed that medical law is concerned with the responsibility of members of the medical profession for their actions. It is also about human rights, moral viewpoints, ethical concepts, economic demands on society and duties owed. ${ }^{41}$

\section{The Perspective of Health and Consumer Protection Law on Informed Consent}

In health law, the right of patient consent after provision of information (informed consent) is the foundation of relationship between patient and doctor. In Indonesia, the case of Muchjidin in Sukabumi in 1984 is the milestone of informed consent doctrine. ${ }^{42}$ Informed consent was born due to the therapeutic

\footnotetext{
${ }^{39}$ In relationship with patient, doctor does not guarantee the health of patient and does not guarantee that the patient would be cured but must guarantee that the implementation of medical treatment follows the proper procedure. The lack of clarity of this concept could be used as a trap against doctor as any unsatisfied patient could sue the doctor. Law provides protection for doctor in such event unless the doctor do promise health and cure or conduct medical treatment out of procedure. Ellen I. Picard and Gerald B. Robertson, Legal Liability of Doctors and Hospital in Canada, (Canada: Carswell Thompson Professional Publishing, 1996), p. 1-4.

${ }^{40}$ Ellen I. Picard and Gerald B. Robertson, Legal Liability of Doctors and Hospital in Canada, p. 7-8.

${ }^{41}$ Michael Davies, Textbook on Medical Law, (London: Blackstone Press Limited, 1998), p. 2.

${ }^{42}$ In the case of Muchjidin, he gave his signature as a sign of consent without being given adequate information of the risk of the medical treatment. In this case the judge could annul the medical consent by
} 
relationship between medical personnel and patient ${ }^{43}$ in which every party possess rights and responsibilities which must be respected.

If related with KUHPerdata (Kitab UndangUndang Hukum Perdata, Civil Code), there are 4 (four) requirements which must be fulfilled in informed consent: (1) Agreement between those who bind themselves. (2) Competence to enter into an agreement. (3) A certain definite problem. (4) A cause that is not forbidden. ${ }^{44}$ However, the category of informed consent agreement in the relationship is inspanningsverbintenis agreement which is agreement based on effort not resultaatsverbintenis agreement which is agreement based on result. ${ }^{45}$

The informed consent doctrine is of course in opposition with paternalist doctrine where the doctor impose upon themselves the obligation to cure patient and the patient must accept and fulfill obligation requested by the doctor. In this doctrine only the doctor understands medical care and thus the doctor can do no wrong. This argumentation potentially does much harm to patient whose consent is not needed for any medical treatment by the doctor. However, there are exceptions such as in cases emergency, natural disaster and disease when the doctor's treatment could be performed without informed consent. ${ }^{46}$

Related to development from paternalistic to informed consent doctrine, Ellen and Gerald pointed that law in Canada give patient the right to decide whether to undergo treatment or not. ${ }^{47}$ Further, Ellen

law. This case was followed by Fatwa IDI No. 319/P/BA./1988 and adopted in Minister of Health Regulation the Republik of Indonesia No. 585/Men.Kes/Per/IX/1989 on the Consent of Medical Treatment (Persetujuan Tindakan Medik). This case arose out of the fact that the doctor GM. Husaini does not state that the risk of eye operation is "the patient's eye would seem punctured". Http://isugiarti.blogspot. com/2010/01/sejarah-hukum-doktrin-informed-consent.html, accessed on 6th October 2013.

${ }^{43}$ M. Jusuf Hanafiah and Amri Amir, Etika Kedokteran dan Hukum Kesehatan, (Jakarta: Penerbit Buku Kedokteran, 1999), p. 67.

${ }^{44}$ Article 1320 of KUHPerdata.

45 Fred Ameln, Kapita Selekta Hukum Kedokteran, (Jakarta: Grafikatama Jaya, 1991), p. 42-43.

${ }^{46}$ J.K. Mason and R.A. McCall Smith, Law and Medical Ethic, p. 227-228.

${ }^{47}$ Physical contact with the patient is essential in virtually all medical treatment. The doctor may need to palpate the abdomen, use a tongue depressor or attach the electrodes of an electrocardiograph. In these examples, the patient may have given more than mere passive consent and actually have requested the examination or procedure and so it may seem that bodily contact in medical situations differs little from that in the social or sporting context. But there is an important difference in that the parties are not in an equal position because the doctor is far more knowledgeable than the patient about the latter's condition and the available treatment. In the past, when doctors and Gerald stated that, the form of consent ${ }^{48}$ is divided into express consent and implied consent. Consent must possess several elements, which are: (1) Given voluntarily. (2) Given by a patient who has capacity. (3) Referable both to the treatment and to the person who is to administer that treatment. (4) Given by a patient who is informed. ${ }^{49}$

Informed consent emerges out of ethical principles in medical treatment. The principle of autonomy stated that every person is an end in herself and deserves to be treated as an end in herself. Every person is to be treated as a separate person able to govern herself. As such the principle of autonomy is considered as a freedom to act which is only valuable when people respect each other's autonomy. In the field of health law the idea of autonomy principle becomes very important as it is the foundation or acknowledgement of patient's rights of his or her own self. ${ }^{50}$ As such, Peggy Foster stated by citing Ian Kennedy, that "Consent in the context of modem medicine is... an ethical doctrine about respect for persons and about power." ${ }^{1}$

A further elaboration of autonomy which is very fundamental in health law as stated by Judge Cardozo in Schloendorff $v$. Society of New York Hospital (1914) 105 N.E.92 is "Every person being of adult years and sound mind has a right to determine what shall be done with his own body." ${ }^{52}$ This elaboration of autonomy is very closely related to the concept of ownership as the basis of the principle of autonomy is ownership which is ownership of the patient's body to undergo medical treatment. ${ }^{53}$ As such medical ethics rest on patient autonomy or patient acceptance of health care. However, the lack of medical knowledge and fear of

occupied more of a paternal role there were fewer problems with consent because most patients expected and accepted the doctor's direction. While some modem patients continue to accept this traditional model of the doctor-patient relationship, many do not and want to know more about the medical treatment or procedure involved including the possible risks and available alternatives. As we shall see, this right to a thorough disclosure of information about proposed treatment is now firmly entrenched in Canadian law, as is the patient's right ultimately to decide whether or not to undergo that treatment. Ellen I. Picard and Gerald B. Robertson, Legal Liability of Doctors and Hospital in Canada, p. 40 .

${ }^{48}$ Joseph H. King Jr., The Law of Medical Malpractice, (St. Paul, Minnesota: West Publishing Company, 1986), p. 131-137.

${ }^{49}$ Joseph H. King Jr., The Law of Medical Malpractice, p. 45-55.

${ }^{50}$ John Devereux, Medical Law, (London: Cavendish Publishing, 2002), p. 5.

${ }^{51}$ Peggy Foster, "Informed Consent in Practice", in Sally Sheldon and Michael Thomson (ed), Feminist Perspectives on Health Care Law, (London: Cavendish Publishing Limited, 1998), p. 53.

${ }^{52}$ Andrew Hockton, The Law of Consent to Medical Treatment, (London: Sweet \& Maxwell, 2002), p. 5.

53 Derek Morgan, Issues in Medical Law and Ethics, (London: Ca endish Publishing Limited, 2001), p. 84. 
illness where patient is not equal morally to doctor who has more knowledge, thus patient needs encouragement and respect as an individual to be treated..$^{54}$

In later development, the principle of autonomy which has roots in the principle of ownership evolves into the principle of "beneficence". Devereux stated that:

The countervailing principle to autonomy is often beneficence. The moral duty of beneficence requires medical practitioners to act so as to produce the best medical result for their patient. That is to say they must act so as to promote the wellbeing of the patient. Beneficence may also involve the prevention of harm, the removal of harm, benevolence or compassion. The idea of beneficence is trained to treat, to attempt to cure the patient. ${ }^{55}$

\section{Further Catherine stated:}

The principle of beneficence obliges a doctor to abstain from injuring others and to help others further their legitimate interests by preventing or removing possible harms. It is the responsibility of the medical profession to do good to patients and the public. Beneficence includes efforts to improve the health of a community. ${ }^{56}$

The principle of "beneficence" is reinforced with the principle of "non maleficence". As stated by Catherine non maleficence is the duty to do no harm, an obligation not to inflict harm intentionally. Obligations of beneficence and non maleficence are both expressed in the Hippocratic Oath: "I will follow that system of regimen which according to my ability and judgement, I consider for the benefit of my patients and abstain from whatever is deleterious and mischievous." ${ }^{57}$

The principle of autonomy, beneficence and non maleficence becomes the philosophical foundation of informed consent regime in medical practice. In Indonesia informed consent is formulated in Article 45 Law Number 29 Year 2004 on Medical Practice. Briefly, the article formulates that every medical treatment being performed by a doctor to a patient must be with patient's consent after the patient being given comprehensive information which at least includes: (1) Diagnosis and medical procedure. (2) The purpose of medical procedure. (3) Other alternatives and accompanying risks. (4) Risk and complication which might occur. (5) Prognosis on the medical treatment performed. This consent could be given in writing or verbally however medical treatments which carry with it high risk must

${ }^{54}$ Catherine Tay Swee Kian, Medical Negligence, Get the Law on Your Side, (Singapore: Times Books International, 2001), p. 34-35.

${ }^{55}$ John Devereux, Medical Law, p. 5-6.

${ }^{56}$ Catherine Tay Swee Kian, Medical Negligence, Get the Law on Your Side, p. 35.

${ }^{57}$ Catherine Tay Swee Kian, Medical Negligence, Get the Law on Your Side, p. 35. be performed after written consent signed by those with rights to give consent.

In the perspective of consumer protection law the relationship between doctor and patient could be construed in terms of relationship between health providers and health receivers. ${ }^{58}$ Business English Dictionary define consumer as "A person or company which buys and uses goods and service". ${ }^{59}$ According to Black's Law Dictionary a consumer is "A person who buys goods or service for personal, family or household use with no intention or resale; a natural person who use products for personal rather than business purpose". ${ }^{60}$ While in the Textbook on Consumer Law, a consumer is "One who purchases goods or service". ${ }^{61}$ Law Number 8 Year 1999 on Consumer Protection defines a consumer "Anyone who utilizes goods and/or services available in society, be it for personal, family, other people or creature benefit in which the goods and/or services are not resold". ${ }^{62}$

If a consumer could be defined as above, a patient would be health receiver of goods and/or services (such as medical treatment) while a doctor would be health providers of goods and/or services (again, such as medical treatment). So the health receiver is consumer while the health provider is producer. However, according to Daldiono, eventhough the relationship between a patient and a doctor could be likened to a consumer and a producer as it is permeated with business aspects, ${ }^{63}$ principles contained in consumer protection law also apply to guarantee ${ }^{64}$ patient's rights. ${ }^{65}$

The speech of John F. Kennedy on 15 March 1962 in front of the United States Congress on consumer protection was marked as a new era for consumer protection. This speech obtained much support evidenced by the formation of consumer protection law in the United States a move which was followed by

\footnotetext{
${ }^{58}$ Fred Ameln, Kapita Selekta Hukum Kedokteran, p. 13.

${ }^{59}$ Peter Colin, Business English Dictionary, (London: Linguaphone Institute Limited), p. 60.

${ }^{60}$ Bryan A. Garner, Black's Law Dictionary, p. 335.

${ }^{61}$ David Oughton and John Lowry, Textbook on Consumer Law, (London: Blackstone Press Limited, 1997), p. 1-2.

${ }^{62}$ See Article 1 Number 2 of Law Number 8 Year 1999 on Consumer Protection.

${ }^{63}$ Daldiono, Pasien Pintar dan Dokter Bijak; Buku Wajib bagi Pasien dan Dokter, p. 192-194.

${ }^{64}$ Consumer protection is all effort which guarantees legal certainty to provide protection to consumer. Article 1 Number 1 Law Number 8 Year 1999 on Consumer Protection.

65 Black's Law Dictionary includes a statute that safeguards consumers in the use goods and services. Bryan A. Garner, Black's Law Dictionary, p. 335.
} 
many other states. ${ }^{66}$ The rights mentioned by Kennedy were: (1) The right to safety. (2) The right to choose. (3) The right to be informed. (4) The right to be heard. ${ }^{67}$ These universal consumer rights could be construed as the rights of patients (health receivers) to obtain medical treatment from doctors (health providers) with the following explanation. First, the right to be heard which is the right of patient to be heard concerning the complaints the patient is suffering from such that the doctor can diagnose the patient and determine the medical treatment to be performed.

Second, the right to be informed after presenting complaint of the illness being suffered based on the right to be heard, the patient has the right to obtain information on the diagnosis, medical treatment, treatment alternatives, risk, complication as well as prognosis on the illness being suffered. The right to be informed is one of the foundations of informed consent for the patient from the perspective of consumer protection law.

Third, the right to choose which could be connected with the principle of autonomy in health law where

${ }^{66}$ The speech of John F. Kennedy is an inspiration for the United Nations in which with unanimous agreement the UN General Assembly issued the UN Resolution Number A/RES/39/248 date 16 April 1985 on the guidelines for consumer protection. The consumer rights protected according to this resolution is: (1) The protection of consumers from hazards to their health and safety. (2) The promotion and protection of the economic interests of consumers. (3) Access of consumers to adequate information to enable them to make informed choices according to individual wishes and needs. (4) Consumer education including education on the environmental, social and economic impacts of consumer choice. (5) Availability of effective consumer redress. (6) Freedom to form consumer and other relevant groups or organizations and the opportunity of such organizations to present their views in decision-making processes affecting them. In addition, the European Economic Community defines consumer rights in 5 (five) fundamental rights, which are: (1) The right to protection of health and safety. (2) The right to protection of economic interest. (3) The right of redress. (4) The right to information and education. (5) The right to representation (the right to be heard). The United Kingdom implements the Consumer Protection Act in 1961 which is later amended in 1971. Mexico issued Federal Consumer Protection Act (FCPA) in 1975, Singapore is The Consumer Protection (Trade Description and Safety Requirement Act) (1975), Thailand is Consumer Act (1979), Japan is The Consumer Protection Fundamental Act (1968), Australia is Consumer Affairs Act (1978), Ireland is Consumer Information Act (1978), Finland is Consumer Protection Act (1978) and Canada is The Consumer Protection Act and The Consumer Protection Amendment Act (1971). Munir Fuady, Hukum Bisnis dalam Teori dan Praktek; Buku Kedua, (Bandung: Citra Adtya Bakti, 1994), p. 187. Inosentius Samsul, Perlindungan Konsumen, Kemungkinan Penerapan Tanggung Jawab Mutlak, (Jakarta: Universitas Indonesia, 2004), p. 5. Gunawan Widjaja and Ahmad Yani, Hukum tentang Perlindungan Konsumen, (Jakarta: Gramedia, 2003), p. 15.

67 Inosentius Samsul, Perlindungan Konsumen, Kemungkinan Penerapan Tanggung Jawab Mutlak, p. 7. See also Donald P. Rothschild and David W. Carrol, Consumer Protecting; Reporting Service, (Maryland: National Law Publishing Corporation, 1986), Vol. I, p. 20. the patient has rights upon himself or herself based on the principle of ownership such that the patient has the freedom of choice to accept or reject the medical treatment, acceptance or rejection being the patient prerogative right. It must be understood that the foundation of the right to be informed is the freedom of choice that the patient could make to determine his or her decision. This right determines whether relationship based on informed consent occurs or not.

Fourth, the right to safety which is the final result desired by both patient and doctor. However, it must be emphasized that the bond between patient and doctor is inspanningsverbintenis bond, a bond based on maximum effort to cure patient not resultaatsverbintenis bond, a bond based on result which could guarantee patient's health. The right to safety could be connected with the principle of beneficence and the principle of non maleficence. The idea of beneficence is to attempt to cure the patient while non maleficence is the duty to do no harm, an obligation not to inflict harm intentionally.

One of the argumentations of Inosentius Samsul on the importance ofgovernment intervention for consumer protection is the relationship between consumer and producer is asymmetrical. ${ }^{68}$ This argumentation also supports the idea that the relationship between patient and doctor must be symmetrical in the form of partnership as elaborated by Daldiono previously. Dunggan stated that consumer protection law rest on welfare consideration ${ }^{69}$ as is protection to patient who desires benefit (maslahat) to patient.

Based on the above explanation, the principles of autonomy, beneficence and non maleficence contained in health law or universal rights contained in consumer protection law, which are: (1) The right to safety. (2) The right to choose. (3) The right to be informed. (4) The right to be heard all support the doctrine of informed consent on the relationship between patient and doctor.

\section{The Application of the Concept of Amânah in Informed Consent}

This section is intended not to criticize the Decision of the Supreme Court of the Republic of Indonesia Number $365 \mathrm{~K} / \mathrm{Pid} / 2012$ which is final and binding but to formulate the concept of amânah in informed

\footnotetext{
68 Inosentius Samsul, Perlindungan Konsumen, Kemungkinan Penerapan Tanggung Jawab Mutlak, p. 30.

${ }^{69}$ Stephen Corones and Philip H. Clarke, Consumer Protection and Product Liability Law, Commentary and Materials, (Sydney: LawBook Co, 2002), Second Edition, p. 10-12.
} 
consent. In the Supreme Court decision there are several legal facts related to informed consent, which are: (1) That the Defendants before performing cito secsio sesaria operation on the victim had not conveyed to the victim's family the possibility of event which could befell the victim. (2) That the victim signature contained in the consent form is spurious signature according to the analysis result of Criminal Laboratory NO.LAB: 509/ DTF $/ 2011 .{ }^{70}$ Both facts are sufficient to prove that the implementation of informed consent is closely related to the concept of amânah.

Amânah in Islamic law is very closely related to justice $^{71}$ and justice is indeed one of the criteria of success to fulfill amânah. Majid Khadduri stated:

In the Alquran there are over two hundred admonitions against injustice expressed in such word as zhulm, itsm, dhalâl and others, and no less than almost a hundred expressions embodying the notion of justice, either directly in such word as 'adl, qisth, mîzan and others as noted before or in variety of indirect expression." ${ }^{\prime 2}$

Amânah which must be fulfilled by human as khalîfah fi al-ardh to safeguard the universe is quite burdensome, such that there is dialogue between angel and God, in which the angels question the ability of human to fulfill the amânah. Even the heavens, the earth, and the mountains are reluctant to fulfill the amânah as they are afraid of not fulfilling it. ${ }^{73}$ The burden of amanah which must be fulfilled by humans is supported by the human mind which is also part of the amânah of God to be safeguarded.. ${ }^{74}$

Related to the philosophy of human creation, this means all parts of humans physically, spiritually or mentally are amanah of God including the task of doctor to provide medical treatment to patients and the need of patients to get cure for their disease. As such the concept of amânah must be internalized and crystallized in every human movement as a reflection of slavehood to God. Thus, the relationship between

\footnotetext{
${ }^{70}$ See Putusan Mahkamah Agung Republik Indonesia Nomor $365 \mathrm{~K} / \mathrm{Pid} / 2012$.

${ }^{71}$ Q.s. al-Nisâ' [4]: 58.

${ }^{72}$ Majid Khadduri, The Islamic Conception of Justice, (London: The Johns Hopkins University Press, 1984), p. 10. The theory of justice is a hotly debated topic among philosophers even becoming ideology of the state. John Rawls for example, see justice in duty and obligation of original position where everyone has the same right in obtaining justice without consideration of status. Sayyid Qutb for example, stated that the foundations on which Islamic establishes justice are: (1) Absolute freedom of conscience. (2) The complete equality of all men. (3) The firm mutual responsibility of society. Sayyid Qutb, Social Justice in Islam, (New York: Islamic Publication International, 2000), p. 51.

${ }^{73}$ Q.s. al-Ahzâb [33]: 72.

${ }^{74}$ One of the purposes of maqâshid al-syarîah is preserving the mind. Abû Ishââ Ibrâhîm Al-Syâthibî, al-Muwâfaqât fî Ushûl alSyarîah, p. 16-25.
}

doctor and patient based on informed consent is also part of the relationship build on the framework of amânah. As informed consent is agreement (amânah) given by patient to doctor after obtaining information from the doctor. ${ }^{75}$

Based on this explanation, several levels of the concept of amânah could be elaborated in informed consent, which are: (1) That God gives amânah to doctor to apply maximum effort to cure patients not to guarantee the patient's health, as guarantee of health belongs to God's domain. (2) On the other hand, God has given amânah to patients to maintain their health and life not to surrender their health and life to be guaranteed by doctor's treatment, as the guarantee of health and life belongs to God's domain. (3) In the next level the patient wishes to cure their illness by presenting their complain and requesting help from God who are considered more knowledgeable in medicine compared to himself or herself, the doctor then provide explanation (information) to patient on the diagnosis, medical treatment, treatment alternatives, risk, complication and prognosis ${ }^{76}$ of the illness being suffered. If the patient agrees ${ }^{77}$ on the medical treatment to be performed, informed consent has been given as amânah to the doctor. This explanation could be defined as the trilogy of amânah concept in informed consent as could be depicted in the following diagram:

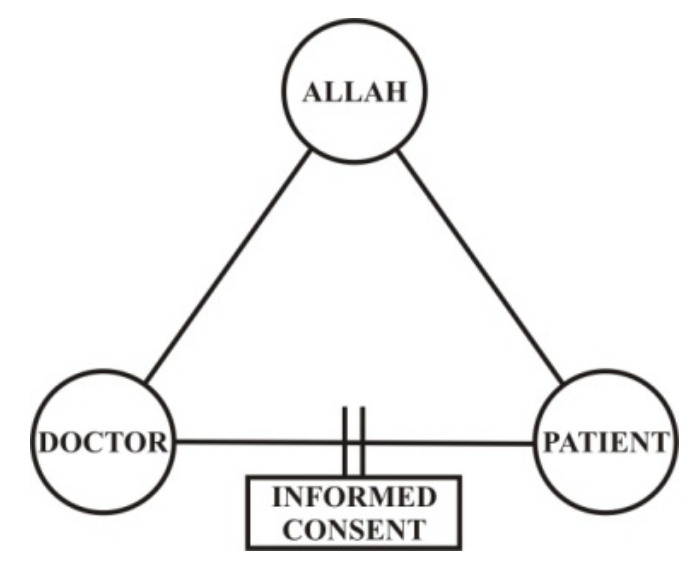

Hence the question arise, can someone guarantee that he or she would always be consistent in fulfilling amânah that is his duty? Can a doctor always fulfill the amânah given to him in providing medical treatment to patient? As such, could someone's fulfillment of amânah be controlled? These questions are difficult to answer

\footnotetext{
${ }^{75}$ M. Jusuf Hanafiah and Amri Amir, Etika Kedokteran dan Hukum Kesehatan, p. 67.

${ }^{76}$ Article 45 Law Number 29 year 2004 on Medical Practice.

${ }^{77}$ See the principle of prinsip autonomy, Andrew Hockton, The Law of Consent to Medical Treatment, p. 5. See also 'The right to Choose', Inosentius Samsul, Perlindungan Konsumen, Kemungkinan Penerapan Tanggung Jawab Mutlak, p. 7. Donald P. Rothschild and David W. Carrol, Consumer Protecting; Reporting Service, p. 20.
} 
precisely but could be elaborated in stages.

The Supreme Court Decision of dr. Dewa Ayu Sasiary Prawani, dr. Hendry Simanjuntak and dr. Hendy Siagian in fact is derived from the understanding and implementation of the concept of amânah in informed consent. Performing cito secsio sesaria operation on the victim without conveying to the family the possibility of events which could befell the victim is not fulfilling amânah. Such is the case for faking signature, an act that does not fulfill amânah. ${ }^{78}$

Except chosen people such as Prophets, not a single person could guarantee the consistency of fulfilling amânah in their course of duty. Abû Bakr who obtained the title al-Shiddîq in his "inauguration speech" requested to be corrected if he goes in the wrong direction. ${ }^{79}$ The Prophet refused to give any position to Abû Dzar as he is deemed weak ${ }^{80}$ in fulfilling amânah which is an indication that academic ability does not necessarily correlate with ability to fulfill amânah. Daldiono elaborated that a wise doctor is a smart and kind doctor. ${ }^{81}$ Kind behavior that fulfills amanah needs to be controlled such that the consistency is maintained, as the behavior of fulfilling amânah could change depending on the condition and situation when amânah is being fulfilled.

The trilogy of amanah concept in informed consent could be a lens to view the practice of medicine in Indonesia, such as follows: first, Article 2 of Law on Medical Practice stated that "The practice of medicine is carried out based on Pancasila and the values on science, benefit, justice, humanity, balance and protection and patient's safety." ${ }^{82}$ Implicitly, the terms of this article has contained the value of amânah as it has been based by Pancasila as the values of humanity, protection, benefit and justice are implicit in Pancasila. However, explicitly the value of amânah is not included in this article, a regrettable fact since this article is hoped to be the spirit of the regulation of relationship between doctor and patient.

Second, every doctor which performs medical practice in Indonesia must have practice license issued by local medical authority in the regency/city where the practice is located and the doctor practice license

\footnotetext{
${ }^{78}$ See Putusan Mahkamah Agung Republik Indonesia Number $365 \mathrm{~K} / \mathrm{Pid} / 2012$.

${ }^{79}$ Charles Kurzman, Modernist Islam 1840-1940, p. $93-94$ and Suzanne McIntire, Speeches in World History, p. 81-81.

${ }^{80}$ Nasiruddin Al-Barabbasi, Kisah-Kisah Islam Anti Korupsi, p. 54.

${ }^{81}$ Daldiono, Pasien Pintar dan Dokter Bijak; Buku Wajib bagi Pasien dan Dokter, p. 199-201.

${ }^{82}$ Article 2 Law Number 29 Year 2004 on Medical Practice.
}

mentioned being given at most to 3 (three) places. ${ }^{83}$ The terms of the location of doctor's practice is regulated in more details in Article 4 Minister of Health's Regulation of the Republic of Indonesia Number 512/MENKES/ PER/IV/2007 on Practice License and Doctor's Practice Implementation. Article 4 clause (1) states "Practice License (Surat Izin Praktik/SIP) of a doctor or dentist is given at most to 3 (three) practice locations, be it in medical service infrastructure of the government, private or individual practice." ${ }^{84}$ Further in Article 4 clause (3) it is stated "SIP of 3 (three) practice locations as mentioned in clause (1) could be located in 1 (one) District/City or other District/City be it in the same Province or other Province." ${ }^{85}$ If this philosophical foundation is welfare and benefit for doctors, this regulation is appropriate as it limits the location of doctor's practice. However, if amannah is used as the philosophical foundation of this regulation hence it is not fully appropriate. A doctor who practices in three different provinces would have to travel a long distance to reach his or her practice place. In a situation where the patient being treated is in emergency condition but the doctor is practicing in a different province could amânah be performed according to informed consent. Could doctor refer his or her patients to other doctor because he is then practicing in other province while he or she is still competent to treat the patient? ${ }^{86}$ Isn't that against the amanah which has been given by the patient based on informed consent? In the perspective of amânah a doctor must be able to gauge his or her ability to fulfill amânah related to practice location. As such, in the perspective of amânah the regulation for location of doctor's practice (not the number of doctor's practice) should be reviewed by considering distance, condition and situation where in major cities there exists a great number of traffic jams. This review is important to be done based on the philosophy of amanah being given to the doctor by the patient based on informed consent.

Third, Article 50 Law Number 29 Year 2004 on Medical Practice stated that "Doctor or dentist when performing medical practice has the right: (1) To

\footnotetext{
${ }^{83}$ See Article 36 and 37 clause (1) and (2) Law Number 29 Year 2004 on Medical Practice.

${ }^{84}$ Article 4 clause (1) Minister of Health Regulation of the Republic of Indonesia Number 512/MENKES/PER/IV/2007 on Practice License and Doctor's Practice Implementation.

85 Article 4 clause (3) Minister of Health Regulation of the Republik of Indonesia Number 512/MENKES/PER/IV/2007 on Practice License and Doctor's Practice Implementation.

${ }^{86}$ Compare with the statement of Article 51 letter b Law Number 29 Year 2004 on Medical Practice which stipulates "Doctor or dentist when practicing medicine has the obligation to refer a patient to another doctor or dentist who has more expertise or ability when they could not perform a treatment or provide medication."
} 
obtain legal protection when performing duty based on professional standard and according to standard operational procedure. (2) To give medical treatment based on professional standard and according to standard operational procedure. (3) To obtain complete and honest information from the patient or his or her family. (4) To receive pay." ${ }^{87}$ The ambiguity in this article could be found in the order of doctor's rights where the stipulation of "To obtain legal protection when performing duty based on professional standard and according to standard operational procedure" is placed as the first right while the amânah given to him or her has not been fulfilled. This stipulation was born out of the defensive attitude of doctor when treating patient, not from his or her offensive attitude in which doctors and patients are both in partnership to fulfill amânah. The stipulation of the legal right should be placed after the stipulation of right "To obtain complete and honest information from the patient or his or her family".

\section{Closing Remarks}

Health is an obligation of every citizen who must be protected by the state. In obtaining their legal rights of health patient has a legal relationship with doctor based on informed consent. The principle of autonomy, beneficence and non maleficence in the perspective of health law as well as the right to safety, the right to choose, the right to be informed and the right to be heard in the perspective of consumer protection law supports and becomes the philosophical foundation of informed consent doctrine in the relationship of doctor and patient. Medical treatment given to the patient based on informed consent must be implemented fulfilling amânah based on the trilogy of amânah concept. []

\section{Bibliography \\ Book/Journal:}

Al-Barabbasi, Nasiruddin, Kisah-Kisah Islam Anti Korupsi, Bandung: Mizania, 2009.

Ameln, Fred, Kapita Selekta Hukum Kedokteran, Jakarta: Grafikatama Jaya, 1991.

Arai-Takahashi, Yutaka, "The Right to Health in International Law; A Critical Apprasial”, in Robyn Martin and Linda Johnson (ed), Law and the Public Dimension of Health, London: Cavendish Publishing Limited, 2001.

Arda, Berna, Informed Consent Right and Children, Beijing: Book of Abstracts, 17th World Congress on Medical Law, 2008.

\footnotetext{
${ }^{87}$ Article 50 Law Number 29 Year 2004 on Medical Practice.
}

Asshiddiqie, Jimly, Konstitusi dan Konstitusionalisme Indonesia, Jakarta: Sekretariat Jenderal dan Kepaniteraan Mahkamah Konstitusi Republik Indonesia, 2006.

Barrî, al-, Zakariyâ, Mashâdir al-Ahkâm al-Islâmiyyah, Mesir: Dâr al-Ittihâd al-'Arabî, 1975.

Bûthî, al-, Muhammad Sa’îd Ramadhân, Zhawâbith al-Mashlabah fî al-Syarîah al-Islâmiyyah, Beirut: Mu'assasah al-Risâlah, 1977.

Chand, Hari, Modern Jurisprudence, Kuala Lumpur: International Law Book Services: 1994.

Chongqi, Wu, Law, Health Law and Science of Health Law, in World Association for Medical Law, AugustDecember 2012, Vol. 4.

Colin, Peter, Business English Dictionary, London: Linguaphone Institute Limited.

Corones, Stephen and Philip H. Clarke, Consumer Protection and Product Liability Law, Commentary and Materials, Sydney: LawBook Co, 2002, Second Edition.

Daldiono, Pasien Pintar dan Dokter Bijak; Buku Wajib bagi Pasien dan Dokter, Jakarta: Buana Ilmu Populer, 2007.

Davies, Michael, Textbook on Medical Law, London: Blackstone Press Limited, 1998.

Devereux, John, Medical Law, London: Cavendish Publishing, 2002.

Dicey, A.V., Introduction to the Study of the Law of the Constitution, Indianapolis: Liberty Fund, 1982.

Feldman, Laurence P., Consumer Protection, Problems and Prospect, St. Paul: West Publishing, 1977.

Foster, Peggy, "Informed Consent in Practice", in Sally Sheldon and Michael Thomson (ed), Feminist Perspectives on Health Care Law, London: Cavendish Publishing Limited, 1998.

Fuady, Munir, Hukum Bisnis dalam Teori dan Praktek; Buku Kedua, Bandung: Citra Adtya Bakti, 1994.

Garner, Bryan A., Black's Law Dictionary, St. Paul, Minn: West Publishing, 2004, Eight Edition.

Hanafiah, M. Jusuf and Amri Amir, Etika Kedokteran dan Hukum Kesehatan, Jakarta: Penerbit Buku Kedokteran, 1999.

Hockton, Andrew, The Law of Consent to Medical Treatment, London: Sweet \& Maxwell, 2002.

Ibn 'Arabî, A $\underline{h} k \hat{a} m$ Al-Qurân, Beirut: Dâr al-Kutub al'Ilmiyyah, 2003.

Kamali, Mohammad Hashim, Principles of Islamic Jurisprudence, Kuala Lumpur: Ilmiah Publisher Sdn., 1998.

Khadduri, Majid, The Islamic Conception of Justice, London: The Johns Hopkins University Press, 1984. 
Kian, Catherine Tay Swee, Medical Negligence, Get the Law on Your Side, Singapore: Times Books International, 2001.

King Jr., Joseph H., The Law of Medical Malpractice, St. Paul, Minnesota: West Publishing Company, 1986.

Kurzman, Charles, Modernist Islam 1840-1940, New York: Oxford University Press, 2002.

Ma’lûf, Loys, Al-Munjid fì al-Lughah, Beirut-Lebanon: Dâr El-Machreq Sarl Publisher, 1986.

Mason, J.K. and R.A. McCall Smith, Law and Medical Ethic, London: Butterworths, 1991.

McIntire, Suzanne, Speeches in World History, New York: An Imprint of Infobase Publishing, 2009.

Morgan, Derek, Issues in Medical Law and Ethics, London: Cavendish Publishing Limited, 2001.

Oughton, David and John Lowry, Textbook on Consumer Law, London: Blackstone Press Limited, 1997.

Picard, Ellen I. and Gerald B. Robertson, Legal Liability of Doctors and Hospital in Canada, Canada: Carswell Thompson Professional Publishing, 1996.

Pusat Bahasa Departemen Pendidikan Nasional, Kamus Besar Bahasa Indonesia, Jakarta: Balai Pustaka, 2005.

Putusan Mahkamah Agung Republik Indonesia Nomor $365 \mathrm{~K} / \mathrm{Pid} / 2012$.

Qutb, Sayyid, Social Justice in Islam, New York: Islamic Publication International, 2000.

Rahardjo, Dawam, Ensiklopedia Alquran; Tafsir Sosial Berdasarkan Konsep-Konsep Kunci, Jakarta: Paramadina, 1996.

Roberia, Paradigma Jaminan Kesehatan Semesta, Proposal Disertasi Universitas Indonesia, 2012.

Rothschild, Donald P. and David W. Carrol, Consumer Protecting; Reporting Service, Maryland: National
Law Publishing Corporation, 1986.

Syâthibî, al-, Abû Ishâa Ibrâhîm, al-Muwâfaqât fî Ushûl al-Syarîah, Beirut: Dâr al-Kutub al-'Ilmiyyah, 2004, Juz II.

Syaykhî, al-, 'Abd Allâh ibn Muhammad ibn 'Abd alRaḩmân ibn Ishâq, Tafsîr Ibn Katsîr Jilid II, translated by M. Abdul Ghoffar E.M, Jakarta: Pustaka Imam Syafi'i, 2005.

Widjaja, Gunawan and Ahmad Yani, Hukum tentang Perlindungan Konsumen, Jakarta: Gramedia, 2003.

\section{Website:}

Anonim, "Health and Human Rights", in http://www. who.int/hhr/en, accessed on 6th October 2013.

Anonim, "IDI Sesalkan Penggunaan KUHP pada Kasus Tindakan Medis Dokter", in http://health.okezone. com, accessed on 2nd October 2013.

Http://isugiarti.blogspot.com/2010/01/sejarahhukum-doktrin-informed-consent.html, accessed on 6th October 2013.

Http://www.who.int/about/history/en/index.html, accessed on 6th Juli 2013.

Republika Online, "Politikus Minta Kriminalisasi Dokter Disikapi secara Arif”, in http://www.republika. co.id/berita/nasional/hukum, accessed on 2nd October 2013.

Sindonews.com, "Demo Dokter", in http://daerah. sindonews.com, accessed on 2nd October 2013.

Tempo.com, "Menyoal Demonstrasi Dokter", Friday, in http://www.tempo.co/read/kolom, accessed on 3th October 2013.

Tribunnews.com, "Dokter Mogok Nasional”, in http:// www.tribunnews.com/kesehatan, accessed on 2nd October 2013. 